\title{
Tahfiz Learning and Public Speaking Empowerment using Hadith of al-Qasas al- Nabawi at Tahfiz Institutions in Malaysia
}

\author{
Muhammad Arif Yahya \\ Ahmad Yunus Mohd Noor \\ Mazlan Ibrahim \\ Mohd Haidhar Kamarzaman (Corresponding Author) \\ Wan Haslan Khairuddin \\ Siddig Ahmad \\ Research Centre for Theology and Philosophy \\ Faculty of Islamic Studies \\ The National University of Malaysia \\ 43600, Bangi, Selangor, Malaysia
}

\begin{abstract}
Establishing a balanced curriculum for students is a requirement emphasised on in the National Tahfiz Education Policy (DPTN) of Malaysia. The main focus of the curriculum for tahfiz students is emphasis on the Quran while also keeping others in mind, while co-curriculum activities are aimed at improving the skills of these students. The empowerment of public speaking skills among tahfiz students is focused on those who have previously performed well in activities such as Qasidah performances (performance praising the Prophet), Tahlil sessions (recitation of zikir and prayer), and Council and community service programmes. The need to prepare tahfiz students with the skills to speak in public is in preparation for their dealing with the community after they graduate. This study focused on the hadith of al-Qasas al-Nabawi which contains story elements that can be used by tahfiz students as material to perform preaching activities. The methodology adopted in this study is qualitative by analysing the hadiths contained in al-Qasas al-Nabawi's book Sahih al-Qasas al-Nabawi and Qisas al-Ghayb fi Sahih al-Hadith al-Nabawi. Interviews were also conducted to obtain information on the co-curriculum activities conducted in tahfiz schools in Malaysia, especially those in the form of public speaking and sermons. The study found that the hadiths in the al-Qasasal-Nabawi category can be used as material to conduct preaching activities amongst tahfiz students as the hadiths consist of appropriate story material. This exercise can also be an additional activity for tahfiz students to strengthen their public speaking skills. This therefore implies that al-Qasas al-Nabawi's hadithbased sermon training is able to provide new exposure to tahfiz students as well as complement their sources of knowledge based on the Quran and Hadiths.
\end{abstract}

Keywords: sermon, Tahfiz students, co-curriculum, al-Qasas al-Nabawi

\section{Introduction}

The philosophy of Islamic education emphasises on the aspect of balance when nurturing a student based on his or her spiritual, physical, intellectual, emotional and social elements (The Philosophy of Islamic Education, Ministry of Education, Malaysia). Empowerment of the co-curriculum in tahfiz education, especially the element of skill, has been touched upon by several studies of late (Nor Hayati Fatmi Talib et al., 2017; Solahuddin Ismail, 2016; Hasniza Tawyer et al., 2016). Islamic education is an important matter as it involves all pertinent aspects of life; thus, it should be established in the society in a more balanced manner. Tahfiz institutions are one of the platforms for the society to establish an understanding about Islam, besides other religious schools. Moreover, tahfiz institutions produce students who have a good command of Al-Quran and this surely leads to good virtues and desirable contributions towards the society due to the virtuous nature of Al-Quran that they have faith in. The emphasis on Al-Quran is intended to help form the direction in developing tahfiz graduates' marketability which is also one of the challenges of contemporary education. Khutbah or public speaking is a skill that should be developed early at the school level to eradicate the phobia of public speaking at the tertiary education level (Mohd Efendi 2010 ). According to the President of the Madrasah Tahfiz al-Quran Association of Malaysia (PERMATA), Manolito Dahlan, there is yet to exist a Khutbah Training Module for co-curriculum activities that can be implemented in tahfiz schools (Manolito Dahlan, 2018). Focusing only on the hafazan of Al-Quran without balance in other aspects may render tahfiz students incapable of managing basic tasks in the society, especially public speaking (Muhammad Arif Yahya, 2018).

This study discusses Hadiths of al-Qasas al-Nabawi as proposed material for Malaysian tahfiz students to use to deliver khutbahs as part of their co-curriculum activities. 


\section{Tahfiz Education and Co-Curriculum Activities}

Tahfiz education needs to be enhanced and implemented comprehensively. Doing so does not only involve students' curriculum but also co-curriculum in order to strike a balance and provide what is needed by students to effectively function in society in the future. According to Kamus Dewan (4th Edition), "co-curriculum" is defined as an activity that is part of the main curriculum but differs from the subjects taught in the classroom. However, it is presumed to be part of the student's education course in school. Examples are activities related to associations, sports, et cetera. This definition means that co-curriculum is part of the education course that helps mould a balanced kind of teaching that is not bound by classroom activities. Co-curriculum activities mostly relate to activities outside the classroom that can enhance students' knowledge and skills in their respective fields of study. Besides emphasising on the integration of education and delivering knowledge, the Islamic education philosophy also emphasises that teaching should contain elements that enhance a Muslim's skills and potential in reference to his spiritual, physical, intellectual, emotional and social aspects. However, from an educationist's perspective, it refers to the total development of a student's potential including his cognitive, psychomotor or affective potentials (Abdul Halim Tamuri and Mohamad Khairul Azman Ajuhary, 2010). Based on this definition, Islamic education greatly emphasises on co-curriculum activities related to Islamic education subjects in order to form a balanced kind of teaching that eventually fulfils the established objectives and philosophy of education. In addition, teaching and learning activities under Islamic education should be constantly evaluated so that any shortcoming can be corrected and improved (Mohd Roslan \& Wan Mohd Tarmizi : 2011).

The Malaysian Tahfiz Institution Model can be categorised into four types, namely Tahfiz Dini (Tahfiz Curriculum together with Islamic Education Curriculum), Tahfiz Science (Tahfiz Curriculum together with Science Curriculum), Tahfiz Skills (Tahfiz Curriculum together with Skills Curriculum) and Tahfiz Turath (Tahfiz Curriculum together with the Torah Scripture Curriculum). Each type is a combination of the tahfiz curriculum and another module (Musa Ahmad, 2018). Among the types of co-curriculum activities conducted in tahfiz schools are sports and games, uniform bodies, clubs and associations, hobbies and recreation, Islamic art (nasyid, qasidah and love for the Messenger), public speaking, and social service (Musa Ahmad: 2018). Some examples of cocurriculum activities implemented in tahfizmadrasahs in Malaysia are sports and games such as archery, pingpong, badminton, volleyball, netball, bowling, equestrian, golf and chess, whereas activities related to clubs and associations are such as the Science and Mathematics Club, Robotics Club, Innovation Club, Nasyid Club, Tarannum Club, Language Club and Debating Club.

Meanwhile, uniform clubs consist of Karate, Taekwondo and Silat (Musa Ahmad : 2018). Co-curriculum activities carried out by tahfiz students generally involve tahfiz institutions either public or private, and most of these institutions are financially and administratively stable since these activities come with a high cost. Some tahfiz schools have limited funds. Many are in need of financial assistance (Mohd Kazim Elias : 2018) and face difficulty in implementing high-cost co-curriculum activities. Nevertheless, tahfiz institutions do place great importance on developing students' personality through co-curriculum activities and not just focusing on its hafazan curriculum syllabus.

There are tahfiz institutions such as the Maahad Tahfiz al-Quran wa al-Imamah (MATQI) in Klang, Selangor that focuses on agriculture as one form of co-curriculum activity that provides a varied exposure to students. This Maahad Tahfiz was the first to introduce the Agro Tahfiz concept in Malaysia by equipping its students with knowledge on agriculture and livestock breeding, usually during weekend classes (Berita Harian, 19 April 2019). This venture had attracted the attention of the Malaysian government through the Minister In-Charge of Religion in the Prime Minister's Department and the Agriculture Minister when they suggested that the Agro Tahfiz concept should be extended to other tahfiz institutions in the country (Malaysiakini: Mujahid Perkenal Agro Tahfiz: 2 March, 2019).

Co-curriculum activities for tahfiz students in the form of cake and pastry-making skills training have been implemented in Madrasah al-Qurra (MAQ) in Alor Gajah, Melaka (Musa Ahmad 2018). However, the cake and pastry-making skills training programme is rarely implemented by tahfiz schools as one of their co-curriculum activities. Besides getting rid of students' boredom during the weekends, these skills are appropriate for tahfiz students as the knowledge allows them to open businesses after they graduate. Hence, the implementation of this programme must be more systematic whereby the programme is recognised and the certificate of course completion is issued by an accredited institution. Therefore, tahfiz institutions need to form extensive and systematic collaborations with related authorities that can issue skills' certificates recognised by the government. The Madrasah al-Qurra (MAQ) implements the Dual National Training System (SLDN) registered with the Department of Skills Development in the Ministry of Human Resources.

Under this programme, the tahfiz is able to offer the Mosque Management Program with its first batch of nine students who graduated in 2018 (Madrasah al-Qurra, 2019). The co-curriculum activities mentioned above are examples of practices carried out in some tahfiz schools in Malaysia to strike a balance in tahfiz students. The human capital element in tahfiz students is developed not only by taking into consideration the hafazan curriculum but also the development of skills and personality through co-curriculum activities. Co-curriculum activities that 
enhance tahfiz students' public speaking skills have been implemented in tahfiz schools; some schools have even carried out khutbah activities. However, there is a lack of a specific khutbah training module based on hadiths in the al-Qasas al-Nabawi (Manolito Dahlan, 2018). Based on feedback obtained on co-curriculum activities in Malaysian tahfiz institutions, especially private institutions, none of these activities was found to be coordinated or systematic; hence, the programmes planned are unable to properly enhance students' capabilities and skills when interacting with society. Programmes and activities that enhance students' capabilities such as training related to preparing and delivering khutbah and public speaking which are important elements for forming a balanced tahfiz student have not been implemented systematically or coordinated well by associations affiliated with Malaysian tahfiz institutions. According to the President of the Madrasah Tahfiz al-Quran Association of Malaysia (PERMATA), Manolito Dahlan, there is yet to be a training module for preparing and delivering khutbah or public speaking in tahfiz schools, which is presently implemented as a co-curriculum activity (Manolito Dahlan 2018). Schools have implemented their own initiatives to enhance public speaking skills among their tahfiz students. For example, activities that are aimed at enhancing public speaking skills are such as the management of tahlil (Manolito Dahlan 2018) and nasyid and marhaban programmes that are incorporated into official programmes in collaboration with the local community (Tarbiah Hafaz Quran Ibnu Sina Centre). These are some of the programmes implemented by several private tahfiz institutions aimed at enhancing tahfiz students' communication skills that is required when interacting with the society. This shows that the type of programme implemented to enhance public speaking skills in tahfiz students is not coordinated and systematic. Studies on enhancing tahfiz students' skills have been conducted by previous researchers as an initiative to enhance the marketability of tahfiz graduates when they venture into the employment world (Nor Hayati Fatmi Talib et al., 2017; Solahuddin Ismail 2016; Hasniza Tawyer et al., 2016). This skill corresponds with tahfiz students' field of study that they have to experience eventually which is the mosque or surau institution where they will have to lead the solat as well as manage ilmiyyah programmes with the society. Thus, when tahfiz students are not equipped with good public speaking skills, they may not be able to interact with society effectively because communication skills are a fundamental requirement in relationships.

One of the obstacles in implementing a more systematic and appropriate co-curriculum programme in tahfiz schools is the lack of funds to administer the programme. Administrators are unable to implement better cocurriculum activities due to the lack of funds. Students' tuition fees are only enough for managing the school such as paying staff's emoluments, food and beverage for students, as well as utility charges (Kazim Elias: 2018). In addition, the inability of trained teachers to teach in tahfiz schools is another problem in the implementation of better co-curriculum activities in tahfiz schools. A better curriculum is one that emphasises on hafazan instead of academics. The development of tahfiz students should be empowered and balanced with the implementation of a co-curriculum that produces tahfiz students who are more knowledgeable and possess better personalities. The national education philosophy also emphasises on the aspect of striking a balance when developing students, including a balance in tahfiz students' intellectual, physical as well as spiritual aspects. One element that should be inculcated in tahfiz students is public speaking skills. This is because when the students finish tahfiz studies and enters the society, most will become leaders by leading the society in daily prayers and delivering the tazkirah. When self-confidence and public speaking skills are not well developed in these students, they may lack selfconfidence even though they are only presenting a short tazkirah.

\section{Al-Qasas al-Nabawi: Definition and Approach}

Al-Qasas is plural (jama') for al-Qissah (kisah). A narrative or story (kisah) is one form of art used to deliver news. Each narrative or story is presumed to be news, but not all news is categorised as a narrative or story. Allah S.W.T delivers news in Al-Quran related to the creation of the sky and earth as well as the creation of angels and the Jin; however, it is not considered as a narrative or story. Therefore, is news related to the Messengers as well as their descendants and what actually occurred presumed to be news that contains narratives? (Umar Sulayman al-Asyqar: 1997, 12). A narrative or story (kisah) is defined as a form of art that is related to an event or action and uses language to deliver the desired intent. Its position is rather special compared to other types of art in the world of literature because of its flexibility, width and diverse intentions as well as the beauty of its methodology (uslub) (Muhammad Sulayman al-Asyqar: 1997, 12). The significance of adding the element of narratives or storytelling in delivery is a form of art that has a strong effect (Umar Sulayman al-Asyqar 1997, 12). The significance of narratives or stories contained in the sources of divine deliverance (wahyu) such as Al-Quran and hadiths indicates that the best narratives or stories are sourced from Al-Quran (QS Yusuf : 3), followed by narratives or stories sourced from the hadiths of the Prophet s.a.w (Umar Sulayman al-Asyqar 1997, 14).

In relation to the al-Qasas al-Nabawi approach which is the focus of the discussion are the works of Abu Ishaq alHuwaini and Umar Sulayman al-Asyqar. Both these literary works apply the same method to select authentic and verified hadiths related to al-Qasas al-Nabawi but apply different methods in other aspects. Among the different methods employed by the writers are those related to choosing the theme found in the hadiths, the number of hadiths discussed as well as the approach used to adduce the lessons imparted at the end of each hadith. The following are discussions on both these literary works. 
1) Literary Work by Abu Ishaq al-Huwaini related to al-Qasas al-Nabawi

Literary work by Abu Ishaq al-Huwaini related to al-Qasas al-Nabawi is entitled Sahih al-Qasas al-Nabawi. 50 hadiths related to al-Qasas al-Nabawi were adduced in the work. The themes and contents of these hadiths varied and included stories about Prophets and others that touched on lessons about life. This work by Abu Ishaq alHuwaini is a brief summary of his work entitled Is'af al-Jarih bi al-Qasas al-Nabawi al-Sahih which is yet to be published(Abu Ishaq al-Huwaini: 1411, 3). The suggestion to summarise this work by including previous hadiths from al-Qasas al-Nabawi without a long summary was given by his peers. Hence, the approach taken by Abu Ishaq al-Huwaini in Sahih al-Qasas al-Nabawi is only intended to adduce previous hadiths without a long write-up about the meanings of hadiths. The lessons from these hadiths are only part of that adduced from the 50 hadiths. Abu Ishaq al-Huwaini had summarised this work with the aim of reaping the benefits of khutbah and tazkirah through the hadiths found in al-Qasas al-Nabawi.

Abu Ishaq al-Huwaini used several methods such as not separating lessons according to certain sequences or themes, only considering authentic or verified hadiths, giving titles to each hadith beginning with "al-Qissah" and arranging the hadiths in sequence where each hadith is referred to the original narrator at the top of the order (alRawi al-A'la), matan hadith (text) and takhrij hadith (a brief note on the source of the hadith), statements regarding Gharib al-Hadis (a kalimah that is strange or one that needs further explanation) only for selected hadiths, and stories that touch on various themes such as stories about Prophets and other Muslims that contain lessons about life as well as things that are undistinguished in the afterlife.

2) Literary Work by Umar Sulayman al-Asyqar related to al-Qasas al-Nabawi

Work by Umar Sulayman al-Asyqar related to al-Qasas al-Nabawi is entitled Qisas al-Ghayb fi Sahih al-Hadith alNabawi and it was published in 1997 by Dar al-Nafais in Jordan. There are 57 lessons related to al-Qasas alNabawi in this literary work which are separated into five sections namely stories about Messengers and Prophets, stories about the supreme powers of Allah S.W.T, stories that indicate the advantages of practicing Islam, stories that provide examples related to a strong faith, as well as stories that provide examples of a weak faith.

The number of hadiths found in each section is as follows:

\begin{tabular}{|l|l|l|}
\hline Num. & $\begin{array}{l}\text { Parts from al-Qasas al-Nabawi found in the } \\
\text { work by Umar Sulayman al-Asyqar }\end{array}$ & $\begin{array}{l}\text { Number of Hadiths } \\
\text { adduced }\end{array}$ \\
\hline $\mathbf{1}$ & Stories about Messengers and Prophets & 21 hadiths \\
\hline $\mathbf{2}$ & Stories about the Supreme Powers of Allah S.W.T & 5 hadiths \\
\hline $\mathbf{3}$ & $\begin{array}{l}\text { Stories that reveal the advantages of practising } \\
\text { Islam }\end{array}$ & 9 hadiths \\
\hline $\mathbf{4}$ & Stories that provide examples about a strong faith & 11 hadiths \\
\hline $\mathbf{5}$ & Stories that provide examples of a weak faith & 11 hadiths \\
\hline
\end{tabular}

Table 1: Division of hadiths in al-Qasas al-Nabawi and number of hadiths in the literary work by Umar Sulayman al-Ashqar

Umar Sulayman al-Asyqar also adduced comparisons between some of these stories, especially stories pertaining to Prophets that are found in the Torah. According to Umar Sulayman al-Asyqar, the reason why he included these stories was to correct factual errors found in the Torah (Umar Sulayman al-Asyqar; 1997, 8). This also indicates that the aim of devolving al-Qasas al-Nabawi was to amend the narratives adduced in the Torah.

Therefore, the reason why Umar Sulayman al-Asyqar adduced stories from the Torah was to compare actual stories based on the hadiths of the Prophet s.a.w. Discussions by Umar Sulayman al-Asyqar on the "Syarah" section for each hadith are very thorough. The methods used by Sulayman al-Ashqar show that the discussions are more systematic compared to discussions by Abu Ishaq al-Huwaini. This is evident based on the five sections classified by Umar Sulayman al-Asyqar in his literary work in order to facilitate a better understanding of the work. The separation into sections was not carried out by Abu Ishaq al-Huwaini except for the separation of each hadith according to the title of each story which is purposed to state the number of the story according to its sequence. Besides that, the work by Abu Ishaq al-Huwaini is too brief, difficult to understand and inappropriate for a layman who is incapable of better understanding of hadiths. Comparatively, Umar Sulayman al-Asyqar adduced the syarah section for each hadith in order to facilitate understanding on the hadiths. Therefore, the work by Umar Sulayman al-Asyqar related to al-Qasas al-Nabawi is better suited for the public's perusal and reading compared to that of Abu Ishaq al-Huwaini, which is suitable for those who have good background knowledge of hadiths.

Some of the al-Qasas al-Nabawi hadiths adduced by Abu Ishaq al-Huwaini are also mentioned by Umar Sulayman al-Ashqar in his book, where some are stories about the existence of Prophet Adam a.s, stories about the demise of 
Prophet Musa a.s and Prophet Sulaiman a.s as well as that pertaining to the utterance of the word InsyaaAllah. There are many stories adduced by Abu Ishaq al-Huwaini that are not mentioned by Umar Sulayman al-Ashqar in his literary work. Among them are stories related to Bani Israel, namely that of a short woman walking along with two tall women, a story about two men from the Bani Israel tribe where one had committed sins and the other prayed to Allah s.w.t, as well as a man from the same tribe who had 1000 Dinar. Similarly, several stories adduced by Umar Sulayman al-Ashqar were not mentioned by Abu Ishaq al-Huwaini. Among them are stories about Prophets such as the demise of Prophet Adam a.s, stories about Prophet Soleh and his clan as well as stories about Prophet Moses a.s and Khidir a.s. These are some of the similarities and differences in both literary works that were studied on in relation to hadiths found in al-Qasas al-Nabawi.

\section{Al-Qasas al-Nabawi - Material for Tahfiz Students to Deliver Sermons during Co-Curriculum Activities}

Al-Qasas al-Nabawi is an appropriate material to be used to prepare and deliver khutbahs. Al-Qasas al-Nabawi is only second in this role compared to stories in Al-Quran because it is sourced from the divine revelation (wahyu) bestowed by Allah The Almighty (Umar Sulayman al-Asyqar: 1997, 5).

Al-Qasas al-Nabawi consists of stories based on various topics told by the Prophet s.a.w, such as occult matters related to the Day of Resurrection and questions about afterlife as well as stories about Prophets and past Muslims that provide lessons in life. Stories that are mixed into the presentation could attract the attention of listeners. Materials for preparing and delivering khutbahs can be further enriched by considering the contents of the stories told by the Prophet s.a.w. Topics related to the occult and afterlife as well as past Muslims can only be taken from naqli sources such as Al-Quran or Hadiths.

Nonetheless, stories sourced from Israiliyyat and are not contrary to syariah Islam can be considered from a historical aspect. Previous studies that had arranged the hadiths in al-Qasas al-Nabawi were carried out by Umar Sulayman al-Asyqar (Qisas al-Ghayb fi Sahih al-Hadith al-Nabawi) and Abu Ishaq al-Huwaini (Sahih al-Qasas alNabawi). The arrangement of scripture by Prof Dr Sulayman al-Asyqar is divided into five sections, namely stories about Prophets and Messengers, stories related to the supreme powers of Allah s.w.t, stories about the advantages of practising Islam, stories that show examples of a strong faith, as well as examples ofa weak faith. On the other hand, Abu Ishaq al-Huwaini's book contains 50 hadiths in which the stories are not divided according to any specific arrangement such as in Sulayman al-Asyqar's work. However, only authentic hadiths were considered, each hadith begins with the title "al-Qissah.." and the stories are numbered in sequence. Each hadith also includes its main narrator (al-Rawi al-A'la), matan hadith (texts) and takhrij hadith (source of the hadith), statement about the Gharib al-Hadis (verses or statements that are strange or need clarification) only for specific hadiths and lastly, stories that touch on various contents such as stories about Prophets and previous Muslims that contain lessons.

The characteristics of hadiths in al-Qasas al-Nabawi that pose as appropriate material for preparing and delivering khutbahs are stories about the occult (Ghayb) that function to attract the attention of listeners.

Another characteristic of hadiths in al-Qasas al-Nabawi is the authentication aspect of the hadith which should comprise trusted sources similar to what was studied by Abu Ishaq al-Huwaini and Umar Sulayman al-Asyqar.

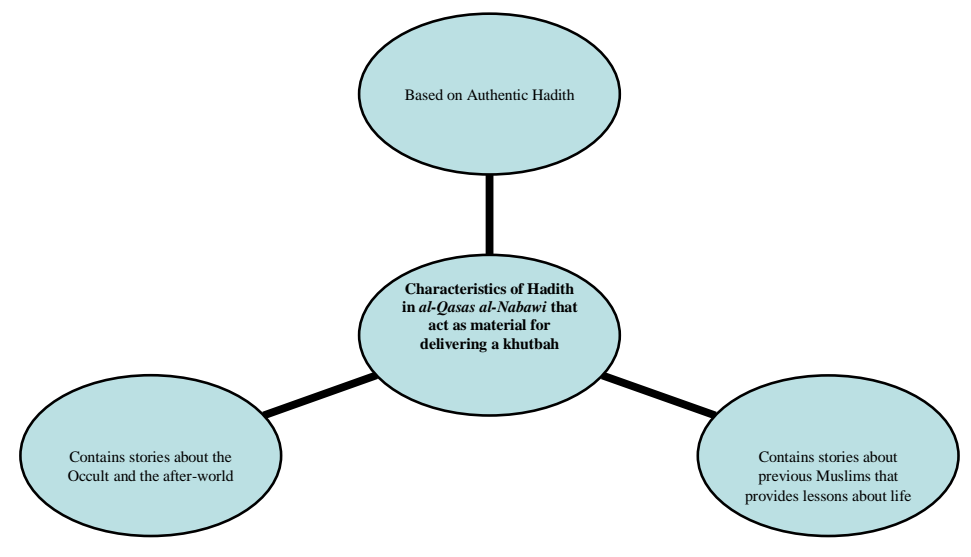

Diagramme 1: Characteristics of hadiths in al-Qasas al-Nabawi that can be used as material for delivering khutbahs

Most hadiths in the Qasasal-Nabawi are attractive and pose as appropriate material for delivering khutbahs. Two references used in the hadiths found in the Qasas al-Nabawi are thought to be the best references related to alQasas al-Nabawi. This is because both these references are based on authentic and verified hadiths. Stories related to unseen matter (Ghayb) and previous Muslims must be sourced from authentic hadiths. Stories found in both these books contain a lot of lessons and can be used as material for tahfiz students when practising or preparing khutbahs. The source of the hadiths can complement tahfiz students' intellectual capacity besides the hafazan curriculum sourced from Al-Quran as khutbah activities are mainly sourced from hadiths. Stories delivered by the 
Prophet s.a.w contain purpose and intent such as enhancing the faith or belief of subjects. These hadiths are authentic and verified. The transition of information into the verbal form such as through speeches, talks and khutbahs can be more attractive when mixed with these stories (Ahmad Saifuddin Yusof et al., 2018).

\section{Conclusion}

Based on the above discussion, it can be concluded that hadiths in the al-Qasas al-Nabawi category can be accepted as material for preparing sermons to be presented by tahfiz students during their co-curriculum activities. An examination of co-curriculum activities in tahfiz institutions especially those in relation to public speaking indicates that there is an absence of a specific module for training tahfiz students to enhance their public speaking skills. Moreover, emphasis on public speaking skills among tahfiz students has not been implemented effectively and only plays a complementary role during tahlil, marhaban and qasidah programmes held together with the local community. Hence, training in public speaking has yet to be introduced as a co-curriculum activity for tahfiz students, especially in private tahfiz institutions. Therefore, it would be better if this training is based on Al-Quran and hadiths and introduced as a specific module in a course appropriate for tahfiz students. The hadiths can become material for preparing khutbahs and tazkirah training sessions or through other forms of co-curriculum activity for these students. This initiative could enhance the marketability of tahfiz graduates as they possess good public speaking skills besides the ability to interact with society more effectively.

\section{Acknowledgements}

The author is very thankful to all associated personnel that contributed to the purpose of this research. This research was financially supported by the University Research Grant Scheme from the National University of Malaysia, UKM Bangi, Selangor [research code GUP-2018-010].

\section{References}

Ahmad Saifuddin Yusof, Ahmad Zahiruddin Mohd Zabidi, Mohamad Lokman Mohd Salleh, 2018, 40 Hadith Sahih Kisah Ghaib dan Ajaib, Seri Kembangan; Firdaus Press.

Abu Ishaq al-Huwayni, 1411, Sahih al-Qasas al-Nabawi, Maktabah al-Sahabah; Jeddah.

Abd Rahman Abd Ghani, Mohd Khafidz Soroni, Noorhafizah Mohd Haridi, Zainora Daud, Azmil Hashim, Wan Sabariah Wan Yusoff, Pengurusan Institusi Tahfiz Persendirian di Negeri Selangor,

Amir Abd Hamid, Sembunyi Rasa Gugup, 2018, surat khabar online: my metro, www.hmetro.com.my, disiarkan pada 24 Mei 2018.

Ghazali Darusalam dan Zaharah Hussain, Kajian Keberkesanan Penyampaian Khutbah Jumaat di Masjid-masjid Wilayah Persekutuan, Kuala Lumpur di dalam; Membangun Institusi Masjid, Jabatan Dakwah dan Pembangunan Insan, Akademi Pengajian Islam, Universiti Malaya, Editor: Norodzoh Hj Siren, Yusmini Md. Yusoff.

Hasniza binti Tawyer, Khairul Aswad bin Ishak, Pendidikan dan Latihan Teknikal dan Vokasional (TVET) dalam Kalangan Pelajar Tahfiz, Persidangan Kebangsaan Pembelajaran Sepanjang Hayat 2016 (PSH 2016), 27 dan 28 September 2016, Fakulti Alam Bina, Universiti Malaya, Kuala Lumpur.

Manolito Dahlan, President of the Madrasah Tahfiz al-Quran Association of Malaysia (PERMATA), was interviewed online on 24 May 2018.

Mohd Saifun Aznin b Mohd Sharif, Ab. Halim Tamuri, Mior Muhammad Saiful Nizan Mohd Saali, Inovation in Teaching and Learning of Hadith Through Stories and Short-stories, Proceedings of the International Conference on Islamic Education 2013 (ICIEd2013), 6-7 April 2013, EPF Institute, Kajang, Selangor Malaysia.

Mujahid Perkenal Tahfiz Agro, 2 March 2019, www.malaysiakini.com/news/466265.

Musa Ahmad, 2018, Wacana Institusi Tahfiz, Dewan Sarjana, Fakulti Pengajian Islam Universiti Kebangsaan Malaysia. Wacana ini telah diadakan pada 20 Disember 2018.

Nor Hayati Fatmi Talib, Bani Hidayat Mohd Shafie, Programme Pengajian Tahfiz dan Asas Penawarannya di Politeknik : Satu Sorotan, 2017, Tinta Artikulasi Membina Ummah 3 (1), 2017, https://www.researchgate.net/publication/318784217_Program_Pengajian_Tahfiz_dan_Asas_Penawarannya_di_Politeknik_Satu_Sorotan.

Norafidah binti Gordani, Abdul Ghafar bin Don, Sukatan Usrah Dalam Membentuk AKhlak Mulia : Kajian di Maahad Tahfiz Wal Tarbiyyah Darul Iman : Satu Dapatan Awal, Jurnal Sultan Alauddin Sulaiman Shah, Vol 4, bil 1, 2017.

Solahuddin bin Ismail, Institusi Tahfiz di Malaysia : prospek dan Cabaran, kertas kerja pembentangan di Simposium Antarabangsa Tahfiz Sempena Sambutan 50 Tahun Jubli Emas Darul Quran, anjuran Darul Quran Jabatan Kemajuan Islam Malaysia (JAKIM), bertempat di Institusi Latihan Islam Malaysia (ILIM), Bangi, Selangor pada 23-24 November 2016.

Umar Sulayman al-Asyqar, 1997, Sahih al-Qasas al-Nabawi, Dar al-Nafais, Amman.

Yusuf Hamdan, Karakteristik Khutbah Jumaat di Masjid Kampus : Perspektif Komunikasi, Vol 8, no 2, 2007, Jurnal Komunikasi, https://ejournal.unisba.ac.id/index.php/mediator/article/view/1261. 